\title{
Enzyme linked immunoassay for early diagnosis of Typhoid fever using Salmonella typhi outer membrane protein
}

\author{
Sylvia Y. Muliawan*, P. Sudarmono, L.H. Moehario
}

\begin{abstract}
Abstrak
Suatu pemeriksaan Indirect Enzyme Linked Immunoassay (ELISA) dengan antigen yang disiapkan dari Salmonella typhi telah digunakan untuk mendeteksi immunoglobulin $M$ antibodi terhadap protein membran luar (OMPs). Sejumlah serum pasien dewasa pada fase akut, minggu pertama yang telah dikonfirmasi dengan kultur sebagai demam tifoid dan serum donor darah telah diperiksa. Dida-

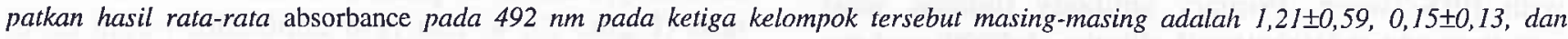
$0,11 \pm 0,08$. Sensitivitas, spesifisitas, nilai duga positif dan nilai duga negatif adalah $81,5 \%, 100 \%, 100 \%$ dan 90,2\%. Dengan menentukan nilai ambang 0,35 dan hasil pemeriksaan ELISA pada serum pasien demam tifoid menunjukkan nilai rata-rata kurang lebih 3,5 kali nilai ambang.
\end{abstract}

\begin{abstract}
An indirect enzyme-linked immunosorbent assay (ELISA) was used to detect immunoglobulin $M$ antibodies against outer membrane protein (OMPs) from Salmonella typhi as the antigen. Acute phase, first week, sera from adult patients with culture confirmed typhoid fever, sera from culture negative suspected typhoid fever and sera from healthy blood donors were tested. Sera from the three groups gave a mean absorbance reading at $492 \mathrm{~nm}$, of $1.21 \pm 0.59,0.15 \pm 0.13$ and $0.11 \pm 0.08$, respectively. The sensitivity, specificity, positive and negative predictive values were $81.5 \%, 100 \%, 100 \%$ and $90.2 \%$, respectively. The cut off value obtained was 0.35 and in which the ELISA test of typhoid fever patients (Group I) showed the mean absorbance reading approximately 3.5 times higher.
\end{abstract}

\section{INTRODUCTION}

Typhoid fever is a major problem in developing countries. In Indonesia the number of cases per year is $360-900$ per 100,000 inhabitants ${ }^{1}$. The serological diagnosis of typhoid fever still relies upon the Widal test, which detects the presence of antibodies to the $\mathrm{O}$ (lipopolysaccharide) and $\mathrm{H}$ (flagellin) antigens derived from Salmonella typhi. According to Schroeder ${ }^{2}$ this test being serological, is non specific, poorly standardized and often confusing. Moreover, it is difficult to interpret in endemic areas, because the antibody titers of the normal population are often not known $^{3}$ and because of the high background titers among the population ${ }^{4}$. Further, the test must be done 2 times to compare the titers of acute phase and convalescent phase sera. Therefore, in an effort to replace the conventional Widal test, many investigators had already developed a serological diagnosis based on detection of antibodies to S. typhi OMPs. OMPs proteins are abundant and exposed on the surface of the cell 5 and being proteins, have immunogenic properties. Previous studies have indicated that OMPs can

Department of Microbiology, Faculty of Medicine University of Indonesia, Jakarta 10320, Indonesia induce immune respons in acute and convalescence phases of typhoid fever ${ }^{6}$. In this study, we examined the ability of OMPs to induce immunoglobulin $M$ ( $\operatorname{IgM})$ antibody in the acute phase of typhoid fever. Furthermore, we also compared Salmonella typhi IgM antibody detection by ELISA with culture to determine the usefulness of ELISA as an early diagnosis for typhoid fever.

\section{MATERIALS AND METHODS}

\section{Human sera}

Human sera were divided into 3 groups as follows: group 1, consisted of 27 sera collected from inpatients with typhoid fever, bacteriologically confirmed; group 2, consisted of 46 sera from in-patients suspected typhoid fever, culture negative. The two groups of sera were collected within one week after onset of disease. Group 3, consisted of 70 sera from healthy blood donors.

\section{OMPs preparations (OMPs)}

OMPs used in this study was derived from clinical isolate of S.typhi and prepared in Laboratory of Microbiology, Faculty of Medicine University of Indonesia using previously described method $7,8,9$. 


\section{ELISA for the detection of antibodies specific to Salmonella typhi OMP}

Microtiter plates (96-well, flat bottom, Sarstedt, USA) were coated overnight at $4^{\circ} \mathrm{C}$ with $100 \mu \mathrm{l}$ OMPs at a concentration of $5 \mu \mathrm{g} / \mathrm{ml}$ protein. Plates were washed 4 times on the next day, with PBS containing $0.1 \%$ Tween-20 (PBS-Tween). Blocking was then carried out by the addition of $200 \mu \mathrm{l} \mathrm{PBS,} \mathrm{pH}$ 7.4 , containing $1 \%$ BSA, $0.1 \%$ Tween- 20 , and incubated for one hour at $37^{\circ} \mathrm{C}$ followed by four washes with PBS-Tween. Primary antibody (human sera) was then added (100 $\mu 1 /$ well, dilution 1:2000) and the plates were incubated for 1 hour at $37^{\circ} \mathrm{C}$. After washed four times with PBS-Tween, $100 \mu$ of Goat Anti-Human IgM-biotin conjugate (Sigma, USA), diluted 1:2000 or $100 \mu \mathrm{l}$ of Goat Anti-Human IgG-biotin conjugate $(1: 2000)$, were added to each well and the plates were incubated for one hour at $37^{\circ} \mathrm{C}$. Plates were then washed 4 times with PBS-Tween. Furthermore. $100 \mu \mathrm{l}$ of Streptavidin-peroxidase labelled (Sigma, USA) diluted 1:2000, was added to each well and the plates were incubated for one hour at $37^{\circ} \mathrm{C}$. Plates were washed five times with PBS-Tween before added with $100 \mu$ of the substrate o-phenylenediamine (OPD) dihydrochloride (Sigma, USA) at the concentration of $0.4 \mathrm{mg} / \mathrm{ml}$. The color was allowed to develop for 30 minutes at room temperature and the reaction was stopped with $50 \mu 11 \mathrm{~N} \mathrm{H}_{2} \mathrm{SO}_{4}$. The absorbance at $492 \mathrm{~nm}$ was measured using a Titertek Multiskan MCC340 ELISA reader (America).

\section{RESULTS AND DISCUSSION}

Table 1. Comparison of S. typhi IgM antibody detection by ELISA with culture

\begin{tabular}{lccc}
\hline & \multicolumn{3}{c}{ culture } \\
\cline { 2 - 4 } & positive & negative \\
\hline IgM positive & 22 & & 0 \\
IgM negative & 5 & & 46 \\
Sensitivity & & $81.5 \%$ & \\
Specificity & & $100 \%$ & \\
PPV & & $100 \%$ & \\
NPV & & $90.2 \%$ & \\
\hline
\end{tabular}

Results of ELISA test using S.typhi OMP preparations as antigen are shown in Figure 1. A significant rise of $\operatorname{IgM}$ antibodies in the sera of confirmed typhoid fever patients (group 1) was observed as compared to control groups, i.e. suspected typhoid fever patients (group 2) and healthy blood donors (group
3), with mean absorbance at $492 \mathrm{~nm} 1.21 \pm 0.59,0.15$ \pm 0.13 and $0.11 \pm 0.08$ respectively. Our results agreed with previous investigators 8,10 , however, there were slight differences probably due to time variation in sera collection and the dilution of sera. The calculated sensitivity in the ELISA was $81.5 \%$, the specificity $100 \%$, and the positive and negative predictive values were $100 \%$ and $90.2 \%$ (Table 1), respectively. In this study we also observed higher titers of IgM antibodies in comparison to IgG antibodies in the sera of typhoid fever patients in the first week of illness (Figure 2), so that IgM antibodies might be of more diagnostic significance than detection of IgG. This conclusion was similar to previous investigator 11 .The cut off value yielded was 0.35 and the ELISA test of typhoid fever patiens (group 1) showed a mean absorbance reading of approximately 3.5 times higher.

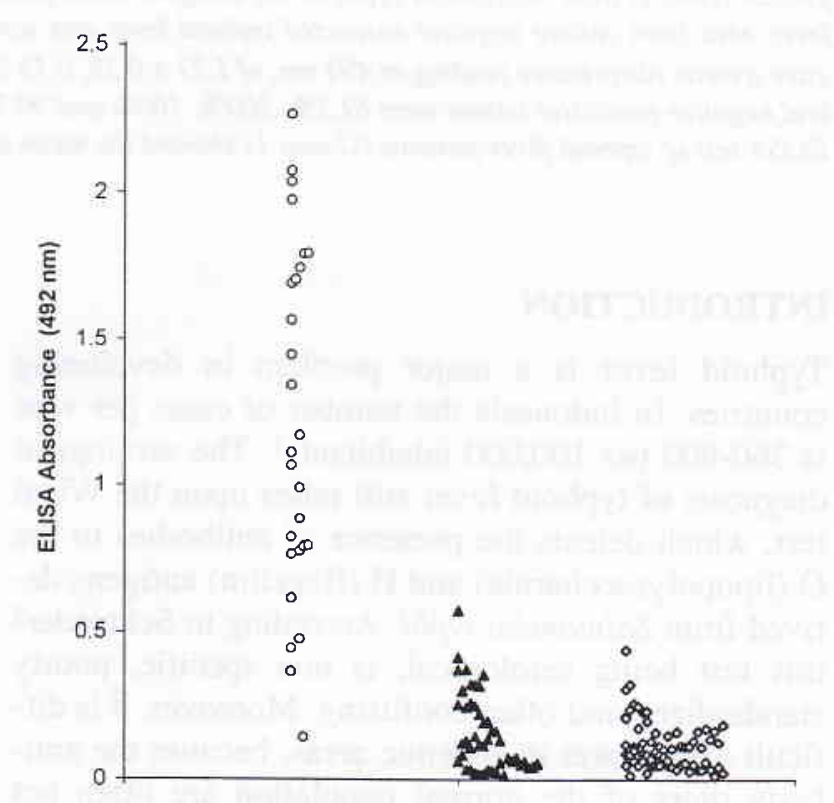

Figure 1. ELISA absorbance readings corresponding to various group of sera.

The first group consisted of 27 patients with confirmed typhoid fever and showed a mean absorbance of $1.21 \pm 0.59$. The second group consisted of 46 patients with suspected typhoid fever with a mean absorbance $0.15 \pm 0.13$. The third group consisted of 70 healthy blood donors and yielded a mean absorbance of $0.11 \pm$ 0.08 .

In summary, the ELISA using OMP preparations of S. typhi as antigen showed high specificity and sensitivity, with value of $100 \%$ and $81.5 \%$ respectively, in comparison to culture method as the gold standard. We were able to demonstrate the presence of $\operatorname{IgM}$ and IgG antibodies in typhoid sera particularly higher 


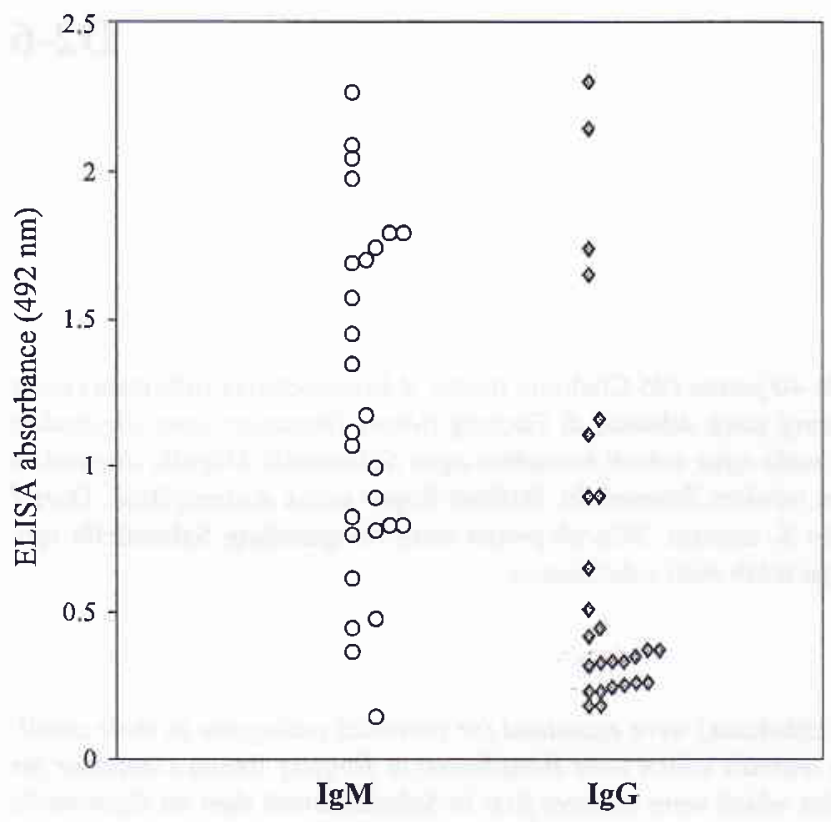

Figure 2. Titer of $\mathrm{IgM}$ and IgG antibodies against Salmonella typhi OMPs in the sera of Typhoid fever patients.

The mean absorbance of $\operatorname{IgM}$ antibodies were higher than IgG antibodies in the sera of typhoid fever patients in the first week of illness. The values were $1.21 \pm 0.59$ and $0.67 \pm 0.12$, respectively.

$\operatorname{IgM}$ titer in the first week of illness. Thus, the results suggested that ELISA test might be used for routine early diagnosis of typhoid fever. The cut off value obtained was 0.35 and the mean absorbance for the typhoid fever patients (group1) was approximately 3.5 times higher.

\section{Acknowledgements}

1. We thanked Sumber Waras Hospital Jakarta-Indonesia and Indonesian Red Cross Blood Transfusion Unit Jakarta for providing the human sera; NAMRU-2 Indonesia for the training.

2. This work was supported by Faculty of Medicine Trisakti University, Jakarta 11140, Indonesia and
CompetetiveReseach Grant(RUT) No. 1004/SPKD/PPIT/IV/95 from Ministry of Research and Technology, Indonesia.

\section{REFERENCES}

1. Simanjuntak $\mathrm{CH}$, Hoffman SL, PunJabi $\mathrm{NH}$, et al. Epidemiology of typhoid fever in Paseh, rural area in West Java. Cermin Dunia Kedokteran 1987; 45:16-8

2. Schrocder SA. Interpretation of serologic tests for typhoid fever. JAMA 1968; 206: 839-40

3. Pang T, Puthucheary SD. Significance and value of the Widal test in the diagnosis of typhoid fever in an endemic area. J Clin Pathol 1983; 36: 471-5

4. Levine $M M$ et al. Diagnostic value of the Widal test in areas endemic for lyphoid fever. Am J Trop Med Hyg 1978; 27(4): $795-800$

5. Nikaido H, Vaara M. Molecular basis of bacterial outer membrane permeability. Microbiol Rev 1985; 49: 1-32

6. Calderon et al. Antibodies to porin antigens of Salmonella typhi induced during lyphoid induced in humans. Inlect Immun 1986; 52(1): 209-12

7. Matsuyama SI, Inokuchi K, Mizushima S. Promoter exchange belween omp $F$ and omp $C$, genes for osmoregulated major outer membrane proteins of Escherichia coli K-12. J Bacteriol 1984; 158(3): 1041-7

8. Rodriguez AV, et al. Detection of antibodies against Salmonella typhi outer membrane protein preparations in typhoid fever patients. Asian Pac J Allergy Immunol 1993; 11: 45-52

9. Moehario HL, Bela B, Sudarmono P. Study of specific protein of Salmonella tuphi for diagnosis of typhoid fever. Southeast Asia J Trop Med and Public Health 1995; 26(2): $230-2$

10. Rodriguez AV, et al. Early diagnosis of typhoid fever by an EIA using Salmonella twphi Outer Membrane Protein preparations. Eur J Clin Mic Infect Dis 1993; 12(4): 248-54

11. Sippel J, et al. Indirect immunoglobulin G (IgG) and IgM Enzyme-Linked Immunosorbent Assays (ELISAs) and JgM capture ELISA for detection of antibodies to lipopolvsaccharide in adult typhoid fever patients in Pakistan. J Clin Microbiol 1989; 27(6): 1298-302 